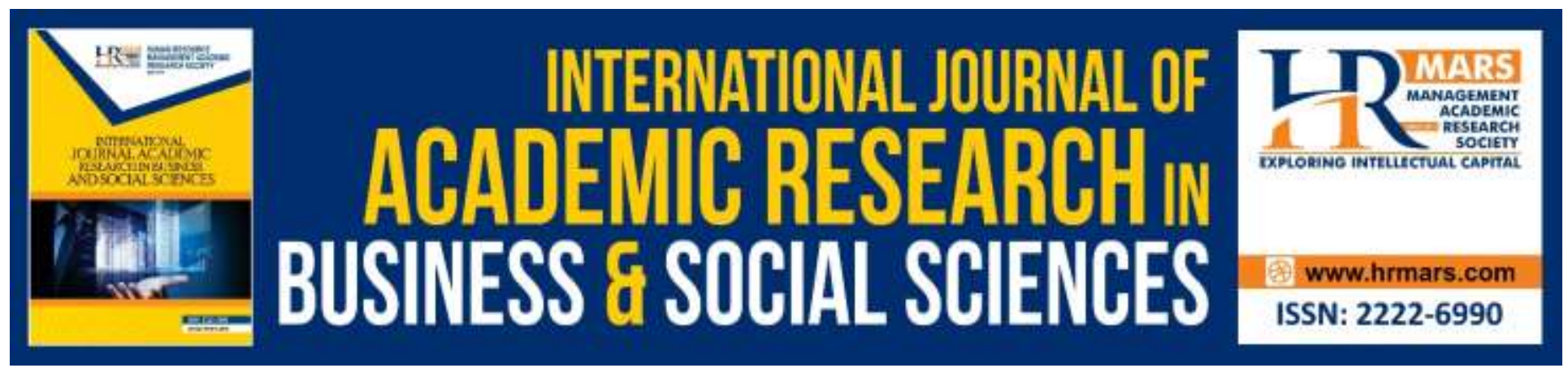

\title{
The Effect of the Cellular Respiration Project-Based Learning Module on Matriculation Students' Achievement
}

Fairuz Aliaa Fadzil \& Siti Nur Diyana Mahmud

To Link this Article: http://dx.doi.org/10.6007/IJARBSS/v10-i1/6810
DOI:10.6007/IJARBSS/v10-i1/6810

Received: 22 December 2019, Revised: 02 January 2020, Accepted: 15 January 2020

Published Online: 30 January 2020

In-Text Citation: (Fadzil \& Mahmud, 2020)

To Cite this Article: Fadzil, F. A., \& Mahmud, S. N. D. (2020). The Effect of the Cellular Respiration Project-Based Learning Module on Matriculation Students' Achievement. International Journal of Academic Research in Business and Social Sciences, 10(1), 93-110.

Copyright: (C) 2020 The Author(s)

Published by Human Resource Management Academic Research Society (www.hrmars.com)

This article is published under the Creative Commons Attribution (CC BY 4.0) license. Anyone may reproduce, distribute, translate and create derivative works of this article (for both commercial and non-commercial purposes), subject to full attribution to the original publication and authors. The full terms of this license may be seen at: http://creativecommons.org/licences/by/4.0/legalcode

Vol. 10, No. 1, 2020, Pg. 93 - 110

Full Terms \& Conditions of access and use can be found at http://hrmars.com/index.php/pages/detail/publication-ethics 


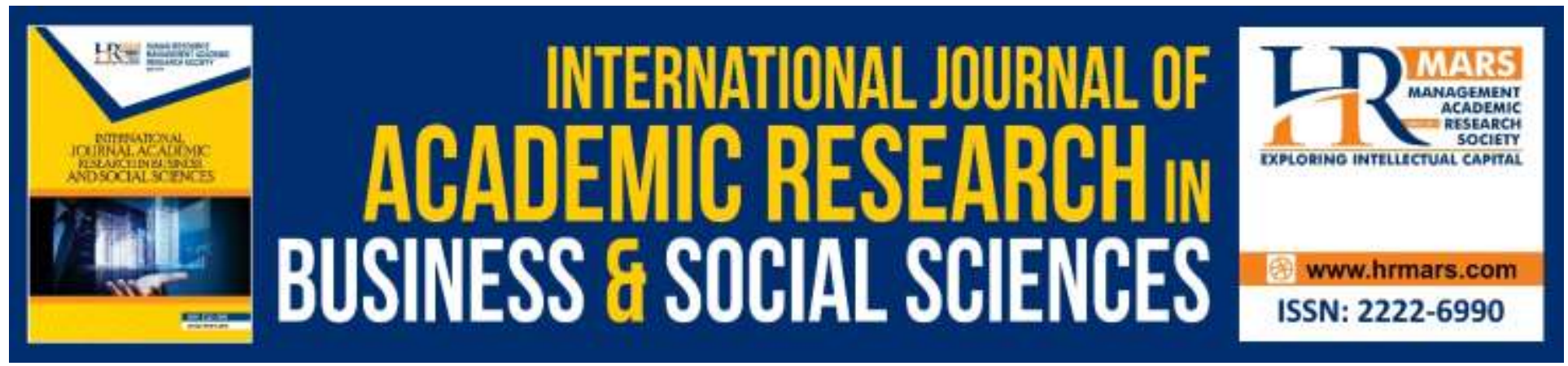

\title{
The Effect of the Cellular Respiration Project-Based Learning Module on Matriculation Students' Achievement
}

\author{
Fairuz Aliaa Fadzil \& Siti Nur Diyana Mahmud \\ Faculty of Education, Universiti Kebangsaan Malaysia, Bangi
}

\begin{abstract}
Biology is one of the important knowledge disciplines in the field of science, technology, and innovation that need to be mastered by students. However, many students have found that several of the concepts in biology are hard, including the Cellular Respiration topic in the Malaysian Ministry of Education Matriculation Programme's curriculum. The teaching and learning strategies in matriculation need to be improved and innovative strategies need to be implemented to make positive changes to student learning. Thus, the Cellular Respiration Project-Based Learning Module (PBL Module) was developed to aid students in learning the Cellular Respiration topic. The PBL Module was developed based on the innovative learning approach known as project-based learning and embedded with a few relevant learning theories. Students are required to run projects collaboratively and produce learning products creatively. A quasi-experimental approach with a pre-test/post-test, nonequivalent control group research design was carried out to test the effect of the PBL Module on students' achievement. 73 matriculation students (19 males and 54 females) from a matriculation college were involved in this research. Two classes were chosen randomly as the treatment group and two classes as the control group. The treatment group learned the Cellular Respiration topic using the PBL Module whilst the control group was taught using the conventional method. The Cellular Respiration Achievement Test (CRAT) was used as the research instrument. The independent-sample t-test showed non-significant differences in the mean scores of the achievement between the treatment group and the control group. Nevertheless, the PBL Module has implications in integrating project-based learning systematically in matriculation, especially in the teaching and learning practices of the biology curriculum.
\end{abstract}

Keywords: Project-Based Learning, Learning Module, Cellular Respiration, Matriculation, Quasiexperiment 


\section{Introduction}

Biology is one of the subjects for the Malaysian Ministry of Education (MOE) Matriculation Program, which is the basis for students to pursue tertiary education in biology and careers related to science and technology (Education Policy Planning and Research Division, 2017). The rationale of the MOE Matriculation Program Biology curriculum is to provide students with knowledge, practical skills, and critical thinking skills. The mastery of the content knowledge is crucial to ensure high quality students in the field of science, technology, and innovation. Biology is a critical knowledge discipline in the $21^{\text {st }}$ century, where the mastery of knowledge in biology can generate numerous technological innovations and new discoveries in the field of science, technology, and innovation that contribute to community and national development (Campbell, et al., 2018).

\section{Problem Statement}

In order to produce outstanding students in the field of science, technology and innovation through the MOE Matriculation Program, a good academic achievement in biology is required. However, it was recorded in one of the matriculation colleges that at least $23.6 \%$ of the students failed in the MOE Matriculation Program biology final examination in 2015 and $3.41 \%$ of the students in 2016 (Selangor Matriculation College Exam Unit, 2017).

Cellular respiration is a popular topic in the MOE Matriculation Program biology final examination, where questions about this topic were asked in every session from the year 2007 until 2017 (Selangor Matriculation College, 2018). Cellular respiration plays a major role in shaping the biologist's understanding in various aspects of the life system (Anderson, et al., 1990). The cellular respiration topic is critical in understanding a few conceptual schemes which include an organism's metabolism, such as excretion, circulation, respiration, and digestion (Songer \& Mintzes, 1994).

However, cellular respiration is considered hard and complex by many biology students and teachers (Songer \& Mintzes, 1994; Johnson, 2009). Studies have shown that students experienced various misconceptions in the cellular respiration concept (Songer \& Mintzes, 1994; Çakir, et al., 2002; and Johnson, 2009). A few weaknesses of the students' answers were recorded for the cellular respiration questions in the MOE Matriculation Programme biology final examination (Matriculation Division, 2014) showed that the matriculation students were having trouble understanding the abstract concepts in the cellular respiration topic and, subsequently, had difficulty in answering examination questions on the topic. This had a negative implication on students' overall academic achievement.

The learning problem factor in the cellular respiration topic is in part due to the learning approach that promotes the memorisation of the abstract concept (Songer \& Mintzes, 1994). Most of the students only memorised the details in the respiration process and did not focus on the overall process and purpose of cellular respiration (Baines, et al., 2004). The use of the lecture method alone did not produce the desired learning outcomes and the students had trouble placing the concept in a broader biological context (Baines, et al., 2004). 
Teacher-centred teaching and learning provides less opportunity for students to actively engage in learning and thinking critically, creatively, and innovatively, which is one of the key factors in student learning (Malaysian Ministry of Education, 2013). Most matriculation teachers conduct teacher-centred teaching, where the teacher dominantly delivers information to the students and the focus is on answering the practice questions as the time allotted for completing the syllabus is limited (Saad \& Sharif, 2018). The teaching and learning strategies in matriculation need to be improved and innovative strategies need to be implemented to make positive changes to student learning.

Effective teaching and learning in biology requires active student engagement so teachers need to shift to active and student-centred learning (Biggs \& Tang, 2011). Various teaching methods are recommended by the Malaysian Ministry of Education to be implemented during the teaching and learning process of the biology curriculum to encourage active participation of students, including inquiry methods, experiments, discussion methods, simulations, projects, technology usage, field trips, and external resource usage (Curriculum Development Division, 2010). The project-based learning approach is one form of teaching and learning that meets active learning characteristics (Wang, 2008).

Project-based learning that is widely used by educators and students in 21st century learning today (Condliffe et al., 2017) is a systematic model of learning around the project (Thomas, 2000). Project-based learning enables students to take responsibility for their own learning and helps them to develop; as well, it enables students to understand and structure information. Students guide their own knowledge through inquiry, and work collaboratively to study and execute projects that reflect their knowledge. Project-based learning is a key strategy for creating independent thinkers, and students gain a wide range of skills that can build a strong foundation for their future (Bell, 2010). Project-based learning features that play a role in building knowledge and skills are based on the theory of constructivism, which is to build knowledge, in which students actively build knowledge through inquiry processes that incorporate critical thinking skills and problem solving skills (Kokotsaki, Menzies \& Wiggins, 2016). Project-based learning applied to abstract concept learning enables students to be actively involved in the process of project creation and to enhance their academic performance in line with Ergül and Kargın's (2014) study that found that project-based learning in electrical topics had a positive impact on students' academic achievement.

Teaching aids are also important as a support material to make teaching interesting and meaningful and to engage and motivate students (Jamian, Othman \& Hashim, 2012). The learning module is one of the teaching aids that can be used to channel skills and knowledge. The learning module has the potential to be a tool, material, and resource that will impact students. Modular learning emphasises student-centred learning and promotes group activities which in turn enhance collaboration, tolerance, interaction, communication, and collaborative discussions amongst, students (Md. Yassin, Aziz \& Ribu, 2011). The use of modules can also facilitate the teaching process, enhance students' understanding and interest, and increase student motivation for teaching and learning (Sidek \& Jamaludin, 2005). 
In the context of the MOE Matriculation Programme, project-based learning is widely practiced as a continuous assessment activity for students but is less implemented in the teaching and learning process of academic subjects. Learning modules which are collections of sample exam questions and exercises are widely used as training modules for students; but learning modules specific to the learning process of a topic are still lacking. The integration of project-based learning in the form of a learning module is thought to have a positive impact on student learning in learning difficult topics, such as Cellular Respiration.

Studies need to be conducted to improve the teaching and learning of biology in the MOE Matriculation Programme. Therefore, a module called the Cellular Respiration Project-Based Learning Module (PBL Module) that integrates a project-based learning approach whilst learning the topic of Cellular Respiration has been developed in the hope to help improve students' achievement in the topic of Cellular Respiration.

\section{Cellular Respiration Project-Based Learning Module Development}

A learning module is a structured teaching aid that contains information to help students gain new knowledge or skills. The teaching objectives are listed first and the content of the teaching is conveyed step by step and through specific steps (Noah \& Ahmad, 2005).

In this study, the process of developing the Cellular Respiration Project-Based Learning Module (PBL Module) took over the design of the ADDIE Model (Branch, 2009). The ADDIE Model was chosen because it is an integration model that provides guidelines and methods that are easy to follow; as well, the process used is in a systematic manner with a clear framework. The ADDIE model consists of five main phases: analysis, design, development, implementation, and evaluation.

The project activities outlined in the PBL Module were based on the key criteria in the Buck Institute for Education (2015), Buck Gold Standard Project-Based Learning (PBL), and seven key elements in the design of a project, which were the Challenging Problem or Question, Sustained Inquiry, Authenticity, Student Voice and Choice, Reflection, Critique and Revision, and Public Product. The design of the PBL Module also involved the integration of several learning theories into learning activities, such as the constructivism theory, constructionism theory, information processing theory, proximal development zone theory, and creativity theory.

The PBL Module integrated a project-based learning approach as a key approach to its learning activities. Steps to conduct the learning activities were developed based on the Needham (1987) Five - Phases Constructivism instruction model which included the orientation phase, idea triggering, idea restructuring, idea application, and reflection. The first phase was the orientation phase to generate interest and draw attention to the content of the lesson. The second phase was the idea-provoking phase to educate the students about their existing knowledge. The third phase was the idea restructuring phase aimed to create awareness of scientific alternative ideas so that students could re-structure their alternative ideas by modifying, extending or replacing them with more scientific ideas. The next phase was the idea application phase aimed to reinforce structured ideas into new and familiar situations. The final phase was the reflection 
phase aimed to alert the students to the changes in ideas and familiarise them with the new ideas so that they could reflect on the changes in the ideas.

The students were given a minimum of six weeks to produce a learning product based on the questions and driving tasks provided in the PBL Module to gain knowledge of the cellular respiration process through the project activities. The students carried out the project activities in small groups of 5 to 6 people in each group, where the students collaborated to actively seek out information through sources such as the internet using information and communication technologies and learn to manage time and productivity, and communicate effectively, as well as train for leadership skills and, finally, they shared their knowledge with the rest of the group by presenting the final product of their projects.

The project activities outlined in the PBL Module were loaded into each of the sub-topics in the restructuring phase and the idea application phase. There were two types of optional projects included in the idea restructuring phase: the poster project and the Power Point multimedia presentation project, whilst there are three types of optional projects included in the idea application phase which were song composing, role playing and model simulation. In order to obtain more effective learning outcomes, each student group was instructed to select and execute only one type of project in the idea restructuring phase and one type of project in the idea application phase. Freedom and autonomy were given to the students to choose the type of project based on their interests.

For each sub topic, the project was based on the driving question which was aimed to challenge and test the mind. The students undertook the projects to produce learning products to answer the questions posed by the driving questions and were expected to learn and understand the concept of cellular respiration in depth.

Some strengthening contents were developed in the PBL Module to assist the students in learning the Cellular Respiration topic which included Notes, Project Inspirations, and Test Your Understanding. To provide the students with the content of the course, the PBL Module was also included with a short note in the Notes section organised by the syllabus. Important and relevant diagrams on the concept of cellular respiration were employed to aid understanding. QR codes that linked to the virtual network of some video examples of each type of project were included in the Project Inspirations section to provide the students with insights, ideas, and inspiration in implementing their chosen project.

At the end of the project implementation, the students were required to present their learning products in a knowledge-sharing session. To enhance the students' motivation for running projects in groups, the teachers were encouraged to organise inter-group competitions where the selection of winners was determined by evaluating the presentation of the learning outcomes. It was possible to perform the presentation evaluation by using the presentation rubric included in the PBL Module in the rubric section. The presentation rubric outlined the aspects that the students should consider during the project implementation and during the project presentation session. The aspects covered included the objectives, information and ideas, time and material management during the presentations, oral and non-verbal skills, language, 
scientific data accuracy, voice, technology and presentation materials, team member engagement, information resources, group management, authenticity, and creativity.

The expert assessment of the PBL Module involved the validity of the PBL Module by the expert evaluators so that the developed PBL Module could really help the students to master the module objectives as suggested by Noah and Ahmad (2005) and Konting (1998). The expert evaluators were given the PBL Module and, subsequently, filled out the module validity questionnaire after reviewing and reading the module. The expert evaluators provided comments, feedback, and suggestions that were then used as material or ideas for strengthening the PBL Module.

The three expert evaluators involved included a university lecturer in biological education, a senior lecturer in biological education, and a Subject Matter Expert (SME) in the subject of Biology Matriculation Programs. The average percentage of content validity of the PBL Module was $90.47 \%$. The average percentage of this score indicates that the level of content validity of the PBL Module content was high and that the content of the module content was good, according to Tuckman and Waheed (1981) in which $70 \%$ of the achievement was considered to be high. The experiment described below was designed to test the effect of the Cellular Respiration Project-Based Learning Module on matriculation students' achievement in the Cellular Respiration topic.

\section{Purpose and Objective of the Study}

The purpose of this study was to determine the effect of the Cellular Respiration Project-Based Learning Module on matriculation students' achievement in the cellular respiration topic. The study was conducted based on the following objective: to determine whether there is a statistically significant difference in achievement for the cellular respiration topic between students taught using the Cellular Respiration Project-Based Learning Module and students taught using conventional methods.

\section{Hypothesis of the Study}

The following null hypothesis was tested.

$\mathrm{H}_{01}$ - There is no significant difference in the mean post-achievement scores between the treatment group who were taught using the Cellular Respiration Project-Based Learning Module and the control group who were taught using the conventional method.

\section{Methodology}

The purpose of this study was to determine the effect of the Cellular Respiration Project-Based Learning Module (PBL Module) on matriculation students' achievement in the Cellular Respiration topic. The quasi-experimental approach with pre-test/post-test, nonequivalent control group research design was carried out in this research. Two classes were chosen randomly as a treatment group and two classes as a control group. The treatment group learned the Cellular Respiration topic using the PBL Module whilst the control group was taught using the conventional method. 


\section{Population and Sample}

The study population was comprised of all students of the One Year System of the Matriculation Programme at one of the Malaysian matriculation colleges. The study samples were taken from the population by purposive sampling. Through the selection of the objective samples, the selected sample was the best respondent who could provide a source of information to help researchers understand the phenomenon being studied (Creswell, 2012). The treatment group consisted of 38 students whilst the control group consisted of 35 students. The between-group study samples had similarity in terms of knowledge, similarity maturity, and the number of study participants providing assurance of the quality of the study data.

\section{Data Collection Instrument}

The Cellular Respiration Achievement Test (CRAT) adapted from Saad and Sharif's (2018) study was used to measure student achievement in the Cellular Respiration topic. The test contained 40 objective questions and 4 structural questions. All the questions were constructed to represent the entire cognitive domain in the revised version of Bloom's Taxonomy by Krathwohl (2002), namely remembering, understanding, applying, analysing, evaluating, and creating. The questions focused on the level of remembering to enhance student achievement in the Cellular Respiration topic. Students need to remember these abstract concepts to enable them to relate the entire Cellular Respiration topic comprehensively. The CRAT's questions were ensured to test all concepts in the Cellular Respiration topic according to the revised Bloom's cognitive domain. $26 \%$ of the questions in the CRAT tested on glycolysis, $19 \%$ on Krebs cycle, $28 \%$ on oxidative phosphorylation, $16 \%$ on aerobic respiration, $9 \%$ on anaerobic respiration, and $2 \%$ on the mixture of aerobic and anaerobic respiration.

All the questions that had been developed in the CRAT were reviewed by two biology educators who had over 16 years of experience in matriculation biology education. Both lecturers were experienced examiners of the matriculation final examination. This review ensured that the CRAT questions were constructed with accurate content and construct validity, including aspects of the clarity of the questions and answers, the appropriateness of the student's ability level, and questions related to the syllabus.

The pilot test was conducted on 30 biology students in one of the Malaysian matriculation colleges to test the reliability of the CRAT. The answer scripts of the CRAT were reviewed by two expert evaluators based on the scoring scheme provided. For structural questions, the reliability of the evaluators' agreement was assessed using Pearson's correlations amongst the scores given by the two evaluators. The findings showed that the correlations amongst the scores provided by the two evaluators were strong; $r=+0.962, p<0.01$.

Item analysis was also performed to obtain the Difficulty Index (Dif. Index) and Discrimination Index (Disc. Index) for the objective question items in the CRAT. The item difficulty index is an index of the students' correct answers, where the lower the value of the difficulty index means the harder it is. Typically, indices of 0.35 to 0.65 are acceptable (Ariffin, 2003). The discrimination index is a measure that distinguishes between high achievement students and low achievement students (Ariffin, 2003; Zakaria, \& Abdullah, 2018; Iyem, Ozturk, Yıldız, 2018). The scale of 
interpretation of the difficulty index and discrimination index in this study referred to the To (1996) scale. The difficulty indexes and discrimination indexes and their interpretations of the objective question items in the CRAT are shown in Table 1.

Table 1: Difficulty index and the index of discrimination of the objective questions

\begin{tabular}{cccccc}
\hline Question & $\begin{array}{c}\text { Dif. } \\
\text { Index }\end{array}$ & $\begin{array}{c}\text { Disc. } \\
\text { Index }\end{array}$ & Question & $\begin{array}{c}\text { Dif. } \\
\text { Index }\end{array}$ & $\begin{array}{c}\text { Disc. } \\
\text { Index }\end{array}$ \\
\hline 1 & 0.65 & 0.1 & 21 & 0.5 & 0.2 \\
2 & 0.75 & 0.5 & 22 & 0.7 & 0.6 \\
3 & 0.9 & 0.2 & 23 & 0.6 & 0.2 \\
4 & 0.5 & 0 & 24 & 0.65 & 0.5 \\
5 & 0.65 & 0.1 & 25 & 0.65 & 0.5 \\
6 & 0.6 & 0.4 & 26 & 0.7 & 0.6 \\
7 & 0.7 & 0.4 & 27 & 0.7 & 0.4 \\
8 & 0.6 & 0.6 & 28 & 0.3 & 0 \\
9 & 0.55 & 0.5 & 29 & 0.2 & 0 \\
10 & 0.9 & 0.2 & 30 & 0 & 0 \\
11 & 0.35 & 0.7 & 31 & 0.65 & 0.1 \\
12 & 0.75 & 0.5 & 32 & 0.15 & 0.1 \\
13 & 0.8 & 0.4 & 33 & 0.5 & 0.4 \\
14 & 0.8 & 0.4 & 34 & 0.1 & 0.2 \\
15 & 0.25 & 0.3 & 35 & 0.15 & 0.1 \\
16 & 0.35 & 0.7 & 36 & 0.5 & 0 \\
17 & 0.85 & 0.3 & 37 & 0.55 & 0.7 \\
18 & 0.75 & 0.5 & 38 & 0.55 & 0.3 \\
19 & 0.7 & 0.6 & 39 & 0.25 & 0.3 \\
20 & 0.35 & 0.7 & 40 & 0.3 & 0.6 \\
\hline
\end{tabular}

Based on Table 1, there were items that were difficult (item 28, item 29, item 30, and item 35) or less able to distinguish between high and low group students (item 1, item 5, item 31, item 32, and item 36). These items were adapted from the previous matriculation final examination questions which were of high quality. The analysis of the items in this pilot study showed that the items were less appropriate in terms of index discrimination. All the items listed, except for item 5 , were found at the cognitive level considering the most basic level, but the students failed to respond correctly. Item 5 was at the level of analysis. The poor item analysis may have been due to learning and teaching problems and the students involved in the pilot study had not mastered this topic. As discussed, the topic of Cellular Respiration is one of the topics considered difficult in the subject of Biology. The researcher made the decision to keep the items unchanged.

Richardson's formula 20 was used to obtain the reliability of the objective questions. The considered reliability value was at least 0.75 (Ariffin, 2003). In this study, the Richardson 20 value of the objective question was 0.797 . 


\section{Data Collection Process}

The researcher first obtained the research approval from the Ministry of Education's Curriculum Planning and Development Division and the Ministry of Education's Matriculation Division. Permission and approval were obtained for conducting the studies at one of the matriculation colleges. Once the study sample was selected, the researcher conducted a training workshop with the biology teachers involved to explain in detail the procedure for implementing the intervention. The workshop was conducted within two hours to ensure that the teachers fully understood the procedure for implementing the PBL Module intervention and management. The workshops included the effective implementation of the PBL Modules in their respective classes and the coordination of the conventional methods to be implemented.

Prior to the intervention, the pre Cellular Respiration Achievement Test (CRAT) (pre-test) were administered in the first week for all the students to examine the heterogeneity between the control and treatment groups. Subsequently, the treatment group students studied the Cellular Respiration topic using the PBL Module whilst the control group students received conventional learning. The treatment group students were given a PBL Module and were given 6 weeks to carry out a project to produce a learning product related to the concept of cellular respiration. The treatment group students presented the results of the project during the seventh week, evaluated by the teachers using the project presentation rubric provided in the PBL Module. In the ninth week, the CRAT (post-test) was administered to both the control group and the treatment group.

The answer scripts for the pre-test and post-test of the CRAT were evaluated by their respective teachers who were involved in the intervention according to the scoring scheme provided. The data of the pre-test and post-test of the CRAT were included in the IBM SPSS Statistics software version 23.0 for analysis.

\section{Data Analysis}

In this study, the data were quantitative and analysed using the descriptive statistics and inference using IBM SPSS Statistics software version 23.0. The data obtained from pre-test and post-test of the CRAT were analysed using the descriptive statistics of the mean and standard deviation. The descriptive statistics described and compared the students' achievement in the Cellular Respiration topic. The type of inference statistics used in this study was the parametric testing which involved the t-test. To test the null hypothesis of the study, the data of the CRAT were analysed using the independent sample t-tests. In addition, the mean of the pre-test scores for the CRAT for the control and treatment groups were analysed using the independent sample t-tests to examine the homogeneity of both groups in terms of the achievement in the Cellular Respiration topic. 


\section{Findings}

\section{Homogeneity of the Achievement Levels in the Cellular Respiration Topic}

The participants in the treatment and control group were tested on the homogeneity of achievement levels in the Cellular Respiration topic using pre-teaching and learning intervention. Table 2 shows the results of the independent sample t-tests and descriptive statistics for the mean test scores of the pre-test of the CRAT by group.

Table 2: Independent sample t-tests' results and descriptive statistics for the mean test scores of the pre-test of the CRAT by group

\begin{tabular}{|c|c|c|c|c|c|c|c|c|c|}
\hline & \multicolumn{6}{|c|}{ Group } & \multirow{3}{*}{$\mathrm{t}$} & \multirow{3}{*}{ Df. } & \multirow{3}{*}{ Sig. } \\
\hline & \multicolumn{3}{|c|}{ Experimental } & \multicolumn{3}{|c|}{ Control } & & & \\
\hline & $\mathrm{N}$ & Mean & $\begin{array}{c}\text { Std. } \\
\text { deviation }\end{array}$ & $\mathrm{N}$ & Mean & $\begin{array}{c}\text { Std. } \\
\text { deviation }\end{array}$ & & & \\
\hline $\begin{array}{c}\text { Pre-test } \\
\text { of the } \\
\text { CRAT }\end{array}$ & 38 & 16.68 & 6.08 & 35 & 17.49 & 5.95 & 0.57 & 71 & 0.57 \\
\hline
\end{tabular}

Based on Table 2, the descriptive statistics showed that the mean test score of the pre-test of the CRAT of the treatment group (mean $=16.68$, std. deviation $=6.08$ ) was lower than the mean of the control group (mean $=17.49$, std. deviation $=5.95)$. The mean difference in the pre-test scores between the control and treatment groups was 0.80 . The t-test results showed that there was no significant difference between the mean test scores for the pre-test of the CRAT for both the control and treatment groups; $t(71)=0.569, p=0.571(p>0.05)$. This means that, both the control and treatment groups were homogeneous in terms of the achievement level in the Cellular Respiration topic before the teaching and learning intervention.

\section{Descriptive Statistics on the CRAT Scores}

The descriptive statistics analysis was performed on the post-test of the CRAT to show the results after the teaching and learning intervention. The descriptive statistics of the mean test scores of the post-test of the CRAT by group are shown as in Table 3.

Table 3: Descriptive statistics of the test scores of the post-test of the CRAT by group

\begin{tabular}{lccc}
\hline Group & $\mathrm{N}$ & Mean & Std. deviation \\
\hline Experimental & 38 & 67.47 & 8.13 \\
\hline Control & 35 & 67.46 & 10.46 \\
\hline
\end{tabular}

Based on Table 3, the descriptive statistics showed that the mean of the post-test of the CRAT in the treatment group (mean $=67.47$, std. deviation $=8.13$ ) was very similar to the mean of the control group (mean $=67.46$, std. deviation $=10.46)$. It can be concluded that the results of the post-test of the CRAT for both the treatment and control groups were similar. 


\section{Inferential Statistics on the CRAT Scores Normality Test}

The Kolmogorov-Smirnov normality test and the skewness value comparison are used for statistical normality testing. Normality tests are performed to determine whether a variable is normal or not. Data a with normal distribution means that a parametric analysis can be used. The results of the Kolmogorov-Smirnov normality test analysis and the comparison of the skewness scores for the pre-test and post-test of the CRAT are shown in Table 4.

Table 4: Results of the Kolmogorov-Smirnov/skewness analysis of the pre-test and post-test of the CRAT

\begin{tabular}{llcc}
\hline \multirow{2}{*}{ Test } & Kolmogorov-Smirnov / & \multicolumn{2}{c}{ Group } \\
\cline { 3 - 4 } & Skewness & Experimental & Control \\
\hline \multirow{4}{*}{ Pre test } & 0.150 & 0.170 \\
& Statistic & 38 & 35 \\
& Df. & 0.030 & 0.012 \\
& Sig. & 0.075 & 0.665 \\
\hline \multirow{4}{*}{ Post test } & Skewness & 0.115 & 0.077 \\
& Statistic & 38 & 35 \\
& Df. & 0.200 & 0.200 \\
& Sig. & 0.193 & 0.308 \\
\hline
\end{tabular}

Table 4 showed the significant values of the Kolmogorov-Smirnov normality test for the pre-test of the CRAT for the treatment group $(p=0.030)$ and the control group $(p=0.012)$, where $p<0.05$ for both the treatment group and control group. Although the Kolmogorov-Smirnov normality test values for the pre-test of the CRAT for the treatment and control groups were less than 0.05 , in terms of the skewness comparison, the standard error of skewness was between -1 and 1 . This shows that the distribution of the pre-test data of the CRAT for the treatment and control groups were normal.

Table 4 also showed the significant values of the Kolmogorov-Smirnov normality test for the posttest of the CRAT for both the treatment group and control group at $p=0.200$, where $p>0.05$. This means that the distribution of the post-test data of the CRAT for the treatment and control groups were normal.

\section{Differences in the Students' Achievement by Group}

An independent sample t-test was conducted to identify the differences in the students' achievement by group. The null hypothesis tested was as follows.

$\mathrm{H}_{01}$ : There is no significant difference in the mean post-achievement scores between the treatment group who were taught using the Cellular Respiration Project-Based Learning Module and the control group who were taught using the conventional method. 
INTERNATIONAL JOURNAL OF ACADEMIC RESEARCH IN BUSINESS AND SOCIAL SCIENCES

Vol. 10, No. 1, Jan, 2020, E-ISSN: 2222-6990 ๔ 2020 HRMARS

The results of the independent sample t-test analysis are shown in Table 5.

Table 5: Independent sample t-test results for the post-test of the CRAT by group

\begin{tabular}{|c|c|c|c|c|c|c|}
\hline & $\mathrm{N}$ & Mean & Std. deviation & $\mathrm{t}$ & Df. & Sig. \\
\hline Experimental & 38 & 67.47 & 8.13 & \multirow{2}{*}{-0.008} & \multirow{2}{*}{71} & \multirow{2}{*}{0.994} \\
\hline Control & 35 & 67.46 & 10.46 & & & \\
\hline
\end{tabular}

Based on Table 5, the results of the independent sample t-test analysis showed that there was no significant difference in the mean post-achievement scores between the treatment group and the control group; $t=-0.008$ and $p=0.994(p>0.05)$. The treatment group students had higher achievement (mean $=67.47$, std. deviation $=8.13$ ) than the control group students (mean $=67.46$ and std. deviation $=10.46)$. Thus, the null hypothesis $\left(\mathrm{H}_{01}\right)$ was accepted.

\section{Discussions}

Based on the results of the independent sample t-test analysis, it was found that there was no significant difference in the mean post-achievement scores between the treatment group who were taught using the Cellular Respiration Project-Based Learning Module (PBL Module) and the control group who were taught using the conventional method (see Table 5). The findings of this study are in line with the findings of Kizkapan and Bektas (2017), where there was no significant difference in the achievement of the post-control group tests and the treatment group in the topic of matter in chemistry amongst seventh grade students. On the other hand, Ergül and Kargın (2014); Özdemir, Filiz, and Göktepe (2015); and Panasan, Nuangchalerm, and Muang (2010) showed that teaching using project-based learning increased the students' academic achievement on behalf of the experimental group.

The conflict between these studies and the present study may have been caused by the following reasons; one of the factors contributing to this finding was that the control group was comfortable and well-adapted to the conventional method of learning, where the conventional method being the most commonly used method of learning in matriculation. The practise of using practice question collections in conventional teaching classes (Saad \& Sharif, 2018) gave the students an advantage over the treatment group in answering the achievement test questions. For the treatment group, the implementation of the project-based learning approach in the PBL Module emphasised student-centred active learning, affecting the students as they took time to adapt to the change in their way of learning as well as the students faced challenges in running the project, as they were already familiar with conventional learning and unfamiliar with the project-based learning approach. If the project-based learning approach is used more frequently in the future, it is likely that the students will become more familiar with the project-based learning approach and that the achievement differences between the control and treatment groups may be significant.

Another factor was that the treatment group was unable to meet all of the learning objectives during the project execution, where the project focus for each group in this study was based on 
one primary process of aerobic respiration. Whilst the PBL Module contained all the learning objectives related to all the processes involved in aerobic respiration, there were learning objectives that the students could not meet when preparing their own projects as the students focused on learning the objectives of their own projects. The treatment group students learned the objectives apart from their own project's learning objectives by exploring self-information and listening, viewing, and learning from the sharing of other peer groups during the presentation session. In contrast to the control group, where the teachers taught and delivered all the individual learning objectives on the Cellular Respiration topic.

The next factor was that the treatment group considered their project as a task and there may have been students who did not take it seriously; as reported by Çiftçi (2010), students will fail in their learning if they do not take care of their project assignments. In this study, since the projects were carried out in groups and not individually, there were some students who were less concerned about the project, which negatively affects those students' academic achievement.

The findings of this study are also in line with the findings of Han, Capraro, and Capraro (2014) who reported that project-based learning is more beneficial to low-performing students than high-performing and moderate-performing students, where growth rate statistics in lowperforming student math scores were significantly higher compared to high-performing students and moderate-performing students; this was in contrast with the findings of Yoon (2009) who reported that high-performing students received a greater positive impact from student-centred learning. Han, Capraro, and Capraro (2014) concluded that project-based learning approaches have a different impact on student achievement based on the students' academic performance levels. In the context of this study, the participants of the study were One Year System matriculation programme students who were high-performing students (Iksan, Halim \& Osman, 2006) in view of the selection of the students to matriculation based on the good science subject in the Certificate of Education Malaysia. This suggested a justification on the lower impact of the project-based learning on the treatment group that led to non-significant achievement differences with the control group.

\section{Conclusions}

The usage of the Cellular Respiration Project-Based Learning Module in the present study implies that the usage of learning module gave a positive impact on biology education but the content and presentation of the module used could be improved to increase its effectiveness in academic achievement. This study proves that the implementation of project-based learning in biology education can be made through the usage of a learning module, with consideration of the findings and discussions presented. This study contributes to the biology education particularly in the matriculation level to construct effective strategies in applying the constructivist projectbased learning approach.

It was seen that there were a lot of challenges in implementing project-based learning. Since adaptations of students and teachers towards project-based learning were limited in matriculation, students should be exposed to more project-based learning activities, such as simple projects being given throughout the semester in the teaching and learning process of 
academic subjects. Teachers can organise a competition amongst the students and encourage the students to display their projects in a science exhibition to increase the students' motivation in doing projects. Increased adaptations of students towards project-based learning may increase the effectiveness of the project-based learning in academic achievement.

Project-based learning can indicate to teachers who normally use conventional methods of teaching that they ought to change in order to be the students' facilitators. Although a workshop on the implementation of project-based learning had been conducted for teachers before the intervention in the present study, it was seen that the way teachers facilitated the students throughout the intervention period needed to be improved. Thus, more professionalism development in the teaching practice of project-based learning needs to be provided to teachers. This is to ensure that teachers can provide the best guidance to students in implementing projectbased learning successfully and eventually enhances the effectiveness of project-based learning in students' academic achievement.

Projects should be designed not only to increase academic achievement but also to promote various skills in the $21^{\text {st }}$ century which include communication, collaboration, and self-regulation. Effective implementation of project-based learning requires a strong support from the college organisation for teachers that includes the aspects of time and resources which would increase the teachers' motivation in embracing the challenges of applying project-based learning in the pedagogy.

\section{Corresponding Author}

Siti Nur Diyana Mahmud

Faculty of Education

Universiti Kebangsaan Malaysia

Email: diyana@ukm.edu.my

\section{References}

Anderson, C. W., Sheldon, T. H., \& Dubay, J. (1990). The Effects of Instruction on College Nonmajors' Conceptions of Respiration and Photosynthesis. Journal of Research in Science Teaching, 27, 761-776. https://doi.org/10.1002/tea.3660270806

Ariffin, S. R. (2003). Teori, Konsep dan Amalan Dalam Pengukuran dan Penilaian. Pusat Pembangunan Akademik UKM, Malaysia.

Baines, A. T., McVey, M., Rybarczyk, B., Thompson, J. T. \& Wilkins, H. R. (2004). Mystery of the Toxic Flea Dip: An Interactive Approach to Teaching Aerobic Cellular Respiration. Cell Biology Education, 3, 62-68. https://doi.org/10.1187/cbe.03-06-0022

Bell, S. (2010). Project-Based Learning for the 21st Century: Skills for the Future. The Clearing House: A Journal of Educational Strategies, Issues and Ideas 83, 39-43. https://doi.org/10.1080/00098650903505415

Biggs, J. \& Tang, C. (2011). Teaching for Quality Learning at University: The society for Re-search into Higher Education. 4th Edition, McGraw Hill, England.

Branch, R. M. (2009). Instructional Design: The ADDIE Approach, Springer. 
Buck Institute for Education. (2015). Gold Standard PBL: Essential Project Design Elements. http://www.pblworks.org

Çakir, Ö. S., Geban, Ö., \& Yürük, N. (2002). Effectiveness of conceptual change text-oriented instruction on students' understanding of cellular respiration concepts. Biochemistry and Molecular Biology Education, 30, 239-243. https://doi.org/10.1002/bmb.2002.494030040095

Campbell, N. A., Reece, J. B., Urry, L. A., Cain, M. L., Wasserman, S. A., Minorsky, P. V., \& Jackson, R. B. (2018). Biology: A Global Approach. 11th Edition, Pearson Education Limited, England.

Çiftçi, S. (2010). The Opinions of the Teachers in Upper Primary Classes Concerning the Student Performance Tasks. Elementary Education Online, 9, 934-95.

Condliffe, B., Quint, J., Visher, M. G., Bangser, M. R., Sonia, D., Saco, L. \& Nelson, E. (2017). Project-Based Learning A Literature Review. MDRC.

Creswell, J.W. (2012). Educational Research: Planning, Conducting, and Evaluating Quantitative and Qualitative Research. 4th Edition, Pearson, Boston.

Curriculum Development Division. (2010). Spesifikasi Kurikulum Biologi Tingkatan 5. Kementerian Pendidikan Malaysia.

Education Policy Planning and Research Division. (2018). Kurikulum Standard Sekolah Menengah Biologi: Dokumen Standard Kurikulum dan Pentaksiran Tingkatan 4 \& 5. Kementerian Pendidikan Malaysia.

Ergül, N. R., \& Kargın, E. K. (2014). The Effect of Project based Learning on Students' Science Success. Procedia-Social and Behavioral Sciences, 136, 537-541. https://doi.org/10.1016/j.sbspro.2014.05.371

Han, S., Capraro, R., \& Capraro, M. M. (2014). How Science, Technology, Engineering, and Mathematics (STEM) Project-Based Learning (PBL) Affects High, Middle, and Low Achievers Differently: The Impact of Student Factors on Achievement. International Journal of Science and Mathematics Education. https://doi.org/10.1007/s10763-0149526-0

Iksan, Z., Halim, L., \& Osman, K. (2006). Sikap Terhadap Sains dalam Kalangan Pelajar Sains di Peringkat Menengah dan Matrikulasi. Pertanika Journal of Social Science \& Humanity, 14, 131-147

Iyem, C., Ozturk, D.G., Yıldız, F.Z. (2018). Clustering and Clustering Potential in TR 32 Regions Province, International Journal of Academic Research in Accounting, Finance and Management Sciences 8 (3): 336- 345.

Jamian, A. R., Othman, S., \& Hashim, H. (2012). Persepsi Guru Terhadap Penggunaan Kartun dalam Transformasi Pengajaran Penulisan Karangan Bahasa Melayu. Jurnal Pendidikan Bahasa Melayu, 2, 129-140.

Johnson, M. P. (2009). Learning About Cellular Respiration of Scientific Inquiry the Process Illustrating An Active Approach. The American Biology Teacher, 60, 685-689. 
Kızkapan, O., \& Bektaş, O. (2017). The Effect of Project Based Learning on Seventh Grade Students' Academic Achievement. International Journal of Instruction, 10, 37-54. https://doi:10.12973/iji.2017.1013a.

Kokotsaki, D., Menzies, V. \& Wiggins, A. (2016). Project-based learning : A review of the literature. Improving Schools 1-11. doi:10.1177/1365480216659733

Konting, M. M. (1998). Kaedah Penyelidikan Pendidikan. Edisi ke-4, Dewan Bahasa Dan Pustaka, Kuala Lumpur.

Krathwohl, D. R. (2002) A Revision of Bloom's Taxonomy: An Overview. Theory into Practices, 41, 212-218.

Malaysian Ministry of Education. (2013). Pelan Pembangunan Pendidikan Malaysia 2013-2025. Kementerian Pendidikan Malaysia.

Matriculation Division. (2014). Laporan Kerja Calon dan Kertas Soalan (PSPM) Biologi SB026/2 Sesi 2013/2014. Kementerian Pendidikan Malaysia.

Md. Yasin, Z., Aziz, Z. \& Ribu, H. E. (2011). Persepsi guru tentang penggunaan aplikasi pengajaran dan pembelajaran dalam meningkatkan perpaduan dan hubungan etnik. Prosiding Seminar Pendidikan Serantau Ke-5 Tahun 2011, Penerbitan Fakultas Keguruan dan Ilmu Pendidikan, Universiti Riau Pekan baru.

Needham, R. (1987). Children Learning in Science Project: Teaching Strategies for Developing Understanding in Science in the Classroom. A Research project Centre for Studies in Science and Mathematics Education, The University of Leeds, Leeds.

Noah, M. S. \& Ahmad, J. (2005). Pembinaan Modul- Bagaimana Membina Modul Latihan Dan Modul Akademik. Edisi ke-2, Penerbit Universiti Putra Malaysia, Serdang.

Özdemir, A. Ş., Filiz, Y. \& Göktepe, S. (2015). The Effect of Project Based Learning in "Ratio, Proportion and Percentage" Unit on Mathematics Success And Attitude. European Journal of Science and Mathematics Education, 3, 1-13.

Panasan, M., Nuangchalerm, P. \& Muang, A. (2010). Learning Outcomes of Project-Based and Inquiry-Based Learning Activities. Journal of Social Sciences, 6, 252-255.

Saad, M. S., \& Sharif, S. (2018). Effectiveness of Game Robot Learning to Students Achievement for Respiration Topic. World Journal of Management and Behavioral Studies, 6, 15-22. https://doi.org/10.5829/idosi.wjmbs.2018.15.22

Selangor Matriculation College Exam Unit. (2017). Analisis Peperiksaan Kolej Matrikulasi Selangor 2013-2016. Kolej Matrikulasi Selangor.

Selangor Matriculation College. (2018). Outreach Biology Semester 2 2017/2018. Kolej Matrikulasi Selangor.

Songer, C. J., \& Mintzes, J. J. (1994). Understanding Cellular Respiration: An Analysis of Conceptual Change In College Biology. Journal of Research in Science Teaching, 31, 621637. https://doi.org/10.1002/tea.3660310605

Thomas, J. W. (2000). A review of research on Project-Based Learning. San Rafael: Autodesk Foundation.

To, K. (1996). Mengenal Analisis Tes (Pengantar ke Program Komputer Anates). Jurusan Psikologi dan Bimbingan, Bandung. 
Wang, Q. (2008). A Generic Model for Guiding the Integration of ICT into Teaching and Learning. Innovations in Education and Teaching International, 45, 411-419. https://doi.org/10.1080/14703290802377307

Yoon, C. H. (2009). Self-Regulated Learning and Instructional Factors in the Scientific Inquiry of Scientifically Gifted Korean Middle School Students. Gifted Child, 53, 203-216.

Zakaria, N. A., \& Abdullah, C. Z. H. (2018). Crowdsourcing and Library Performance in Digital Age. International Journal of Academic Research in Progressive Education and Development, 7(3), 127-136. 